\title{
Vatoz (Dasyatis pastinaca) Balığı Kas Dokusunun Enzimatik Hidrolizi ve Hidrolizatların Antioksidan ve Bakır Şelatlama Aktivitelerinin Değerlendirilmesi
}

\author{
Ebru Kocadağ Kocazorbaz ${ }^{1}$, Meliha Kanatsızoğlu², Hanife Tuğçe Çeker ${ }^{3}$, Esra Menfaatli4*
}

Geliş / Received: 26/12/2019

Revize / Revised: 18/06/2020

Kabul / Accepted: 18/06/2020

\section{$\overline{\mathbf{o z}}$}

Biyoaktif peptidler canlıların vücut fonksiyonlarına ve sağlığına olumlu etkileri bulunan spesifik protein fragmentleri olup bitkisel, hayvansal, fungal, bakteriyel ve venom kaynaklı olabilmektedir. Farklı protein kaynaklarından keşfedilen biyoaktif peptidlerin çoğu, antihipertansiyon, antioksidan, antitrombotik, antimikrobiyal ve antikanser immünomodülasyon gibi çeşitli biyolojik özellikler göstermiştir. Bu çalışmanın amac1, vatoz (Dasyatis pastinaca) kas dokusu protein hidrolizatının biyolojik aktivitelerinin değerlendirilmesidir. Bu nedenle, vatozun homojenize kas dokusu, esperaz ve tripsin enzimleri tarafindan hidrolize edildi. Enzim/substrat oranı, hidroliz süresi ve derecesi optimize edilerek hidrolizatların antioksidan (CUPRAC yöntemi) ve metal şelatlama (bakır şelatlama) aktiviteleri değerlendirildi.

Anahtar Kelimeler- Biyoaktif Peptid, Enzim Atik Hidroliz, Antioksidan, Esperaz, Tripsin

\footnotetext{
1İletişim: ebru.kocadag.kocazorbaz@ege.edu.tr (https://orcid.org/0000-0001-5611-5235)

Faculty of Science, Department of Biochemistry, Ege University, Izmir

2İletişim: msomen.1994@gmail.com (https://orcid.org/0000-0001-9547-5444)

Faculty of Science, Department of Biochemistry, Ege University, Izmir

3iletişim: tugceker159@gmail.com (https://orcid.org/0000-0001-8874-2241)

Department of Medical Biochemistry, Akdeniz University, Antalya

4*Sorumlu yazar iletişim: esramenfaatli@hotmail.com (https:/orcid.org/0000-0002-2370-6415)

Faculty of Science, Department of Biochemistry, Ege University, Izmir
} 


\title{
Enzymatic Hydrolysis of Stingray (Dasyatis pastinaca) Muscle and Evaluation of Antioxidant and Copper Chelating Activities of the Hydrolysates
}

\begin{abstract}
Bioactive peptides that originate from different sources, such as plant, animal, fungi, bacteria, and venom, are specific protein fragments that have positive effects on the body functions and health of living organisms. Most of the discovered bioactive peptides from different protein sources showed various biological features, such as antihypertension, antioxidant, antithrombotic, antimicrobial, and anticancer immunomodulation. The aim of this study is the evaluation of biological activities of stingray (Dasyatis pastinaca) muscle tissue protein hydrolysate. Therefore, the homogenized muscle tissue of stingray was hydrolyzed by esperase and trypsin enzymes. Enzyme/substrate ratio, hydrolysis time, and degree were optimized. Moreover, the antioxidant (CUPRAC method) and metal chelating (copper chelating) activities of the hydrolysates were evaluated.
\end{abstract}

Keywords- Bioactive Peptide, Enzymatic Hydrolysis, Antioxidant, Esperase, Trypsin 


\begin{tabular}{|c|c|c|}
\hline & $\begin{array}{l}\text { BŞEÜ Fen Bilimleri Dergisi } \\
7(2), 680-687,2020\end{array}$ & $\begin{array}{r}\text { BSEU Journal of Science } \\
\text { DOI: } 10.35193 / \text { bseufbd.665435 }\end{array}$ \\
\hline & & 58-7575 (http://dergipark.gov.tr/bseufbd) \\
\hline
\end{tabular}

\section{INTRODUCTION}

Bioactive peptides are organic substances consisting of amino acids with potential biological activities. A clear majority of bioactive peptides are generated by the enzymatic hydrolysis while some of them exist free in natural sources [1]. They can affect biological processes and impact health through their bioactive characteristics, such as opiate, antithrombotic, antihypertensive, antioxidant, antibacterial, and fungicidal activities [2].

Marine species comprise half of the total global diversity and they are rich sources of novel compounds and natural molecules for drug evaluation [3]. Marine bioactive peptides are derived from by-products of algae, fish, mollusk, and crustacean such as muscles, viscera, skins, trimmings, and shellfish [4]. Fish processing byproduct wastes and underutilized fish proteins are the focus of interest for the production of commercially valuable bioactive components. There are many applications of commercially available nutraceuticals/health foods/functional foods in different countries produced from fish protein hydrolysates [5].

Dasyatispastinaca ( $D$. pastinaca), which is commonly called the stingray, is a marine elasmobranch fish from the Dasyatidae family [6]. There have been several studies to investigate bioactive peptides from stingray [7-10], however, their muscle tissues have yet to be explored for enzymatic hydrolysis-based bioactive peptides. Because of the substrate specificity of the proteases, it is clear that further studies are needed for bioactive peptide research of stingrays. In this paper, we studied enzymatic production of bioactive peptides by enzymatic hydrolysis from stingray ( $D$. pastinaca) muscle and evaluated their biological activities, such as antioxidant and metal chelating activity.

\section{MATERIALS AND METHODS}

\section{A. Materials}

Esperase (Novozyme), trypsin, $N \alpha$-benzoyl-L-arginine 4-nitroanilide hydrochloride (BAPNA), casein, Folin-Ciocalteu's phenol reagent, murexide, trichloroacetic acid (TCA), neocuproin, $\mathrm{CuCl}_{2}, \mathrm{CuSO}_{4}, \mathrm{Na}_{2} \mathrm{CO}_{3}$, $\mathrm{NH}_{4} \mathrm{CH}_{3} \mathrm{CO}_{2}$ were purchased from Sigma Chemical Co. (St. Louis, Mo., U.S.A).

\section{B. Protein extraction from D. pastinaca muscle}

The spines of the stingray were removed in the laboratory and the skin and muscle flesh were separated. Muscle tissues (27.6 g) of D. pastinaca(Figure 1) were cut into small pieces and homogenized in $140 \mathrm{~mL}$ of 50 $\mathrm{mM}$ Tris/Borate buffer $(\mathrm{pH}$ 8.0) with a blender. The crude extract was filtered through glass fiber and centrifuged at $9.000 \mathrm{rpm}$ for $15 \mathrm{~min}$. The supernatant was collected and protein content was measured.

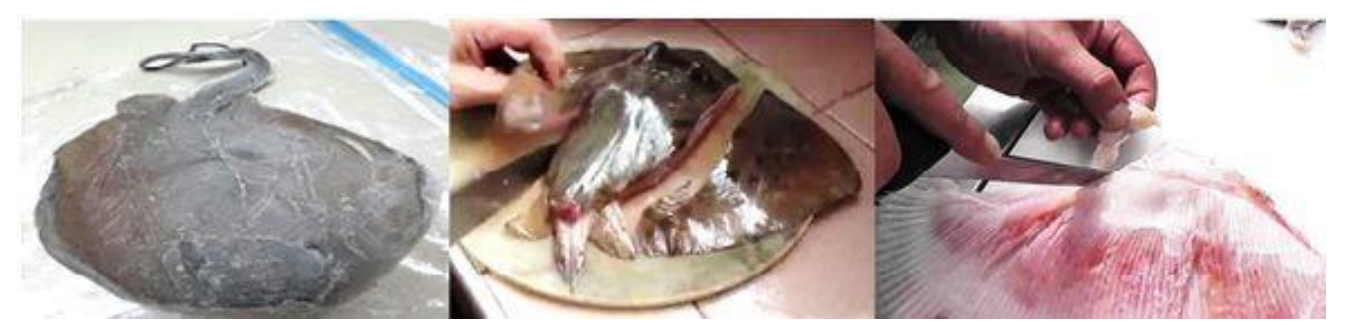

Figure 1. Dasyatis pastinaca fragmentation

\section{Protein and activity assays}

Bradford assay was used to estimate the protein concentrations with some modifications. As the standard known concentrations of bovine serum albumin were used [11]. The proteolytic activity of esperase was estimated with casein as the substrate [12]. The chromogenic substrate BAPNA ( $\mathrm{N}_{\alpha}$-Benzoyl-L-arginine 4nitroanilide hydrochloride) was used for measuring trypsin activity [13]. 


\section{Enzymatic hydrolysis of D. pastinaca muscle}

D. pastinaca muscle extract was denatured thermally to facilitate hydrolysis and inactivate the endogenous enzymes. The protein concentration of the extract was measured. Optimum enzyme/substrate (E/S) (U/mg protein) ratio was determined for both esperase $(6.45 \mathrm{U} / \mathrm{mg})$ and trypsin $(2.17 \mathrm{U} / \mathrm{mg})$. Enzyme/substrate ratios of $1.2,2.4,3.6,7.2$, and 12 were tested to specify the optimum ratio. Muscle extract was incubated with esperase at $50^{\circ} \mathrm{C}$ under constant shaking (300rpm) for $30 \mathrm{~min}$, and the reaction was stopped with TCA (10\%). On the other hand, muscle extract was incubated with trypsin at $37^{\circ} \mathrm{C}$ under constant shaking (300rpm) for 30 min with the same E/S ratios mentioned above, and the reaction was stopped with TCA (10\%). Hydrolysates were centrifuged at $9000 \mathrm{rpm}$ for $10 \mathrm{~min}$ and absorbance of the supernatants was measured at $280 \mathrm{~nm}$. The hydrolysis degree was calculated as the percentage ratio of soluble protein to total protein [14].

$$
\text { Hydrolysis Degree }(\mathrm{DH}) \%=\frac{m g \text { protein after hydrolysis } / m L}{m g \text { protein before hydrolysis } / m L} \times 100
$$

After designating the optimum E/S ratios, the same experiment was performed to determine the optimum incubation time for enzymatic hydrolysis of $D$. pastinaca muscle (30-240 min) with esperase and trypsin.

\section{E. Determination of antioxidant and metal chelating activity of the peptide hydrolysates}

The antioxidant activity of the peptides from $D$. pastinaca muscle hydrolysate was determined using the cupric ions $\left(\mathrm{Cu}^{2+}\right)$ reducing power method (CUPRAC) [15]. Equal volumes of $(25 \mu \mathrm{L}) 10 \mathrm{mM} \mathrm{CuCl}{ }_{2} \cdot 2 \mathrm{H}_{2} \mathrm{O}, 7.5$ $\mathrm{mM}$ neocuproine, and $1 \mathrm{M}$ ammonium acetate buffer at $\mathrm{pH} 7.0$ were pipetted into microplate wells respectively. Samples were added to the reaction solution, incubated for $30 \mathrm{~min}$ at $37^{\circ} \mathrm{C}$, and absorbance was recorded at 450 $\mathrm{nm}$. Ascorbic acid was used as the standard and the total antioxidant capacity was calculated as ascorbic acid equivalent (AAE). The chelating activity of the peptides from D. pastinaca muscle hydrolysate was tested by the tetramethyl murexide (TMM) method [16].

\section{RESULTS}

\section{A. Protein extraction from D. pastinaca muscle}

It is known that different extraction media are used in protein extraction according to the origin of the proteins, their physicochemical characteristics, and the methods to be used in the identification. Both functional and structural properties of the proteins depend on the amino acid sequences. Therefore, it is not possible to obtain all proteins by a single extraction method since their solubility will vary according to the amino acid components. In this study, the crude extract was used to minimize protein loss. The protein concentration of the extract was $3 \mathrm{mg} / \mathrm{mL}$ and the protein acquisition was $12 \mathrm{mg} / \mathrm{g}$ muscle tissue.

\section{B. Optimum hydrolysis conditions for esperase and trypsin}

Enzyme/substrate ratio and incubation time were optimized for enzymatic hydrolysis of D. pastinaca muscle (Table 1). For esperase, as shown in Figure 2, the hydrolysis degree concomitantly increased with the E/S ratio. However, after E/S ratio of 2.4, the rate of increase was fixed thus optimum E/S ratio was chosen as 2.4. The optimum time for hydrolysis was chosen as $2 \mathrm{~h}$ according to the results (Figure 3). The results demonstrated that the optimum enzyme/substrate ratio was 1.2 and the optimum incubation time was $2 \mathrm{~h}$ for hydrolysis of D. pastinaca muscle with trypsin (data not shown). Esperase and especially trypsin are frequently used for protein hydrolysis.

Table 1. Hydrolysis conditions for esperase and trypsin

\begin{tabular}{lcc}
\hline & Esperase & Trypsin \\
\hline Buffer & $50 \mathrm{mM}$ Tris/Borat $(\mathrm{pH} 8.2)$ & $50 \mathrm{mM}$ Tris/Borat $(\mathrm{pH} 8.2)$ \\
Temperature $\left({ }^{\circ} \mathbf{C}\right)$ & 50 & 37 \\
E/S & 2.4 & 1.2 \\
Time (h) & 2 & 2 \\
\hline
\end{tabular}




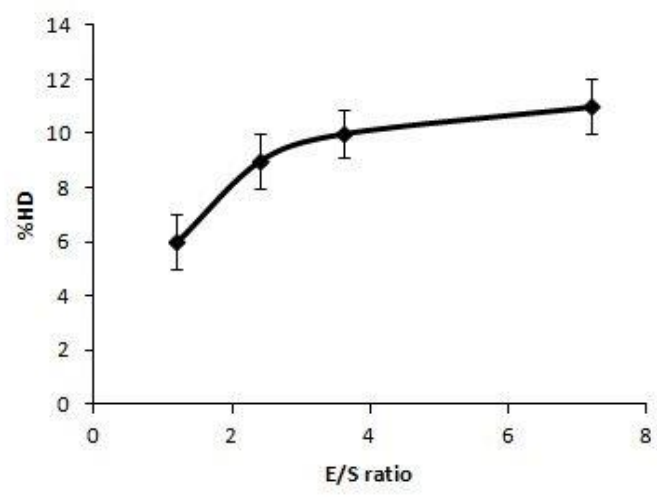

Figure 2. Effect of E/S ratio on the efficiency of hydrolysis for esperase

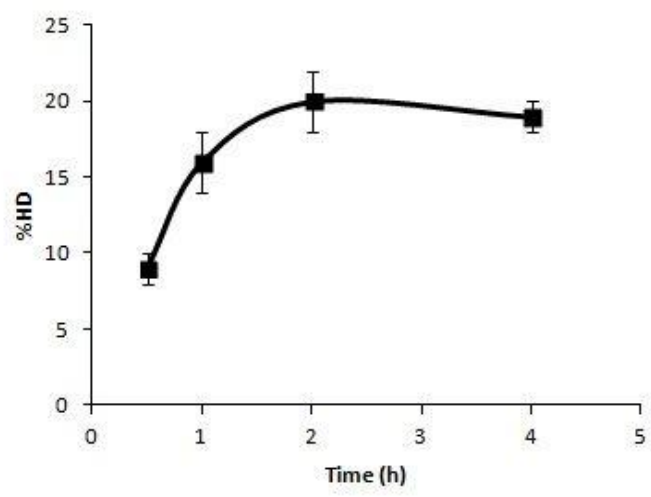

Figure 3. Effect of time on hydrolysis efficiency for esperase

\section{Antioxidant activity of peptide hydrolysates}

We have used the CUPric Reducing Antioxidant Capacity (CUPRAC) method for the total antioxidant activity of the hydrolysates [15]. The results demonstrate that hydrolysis of D. pastinaca muscle with esperase and trypsin reveals protein hydrolysates with efficient antioxidant activity compared to ascorbic acid which is also an effective antioxidant (Table 2). Further investigations are required to enlighten the antioxidant peptide content of the hydrolysates.

Table 2. Antioxidant activities of $D$. pastinaca muscle hydrolysates

\begin{tabular}{lcc}
\hline Hydrolysate & $\begin{array}{c}\text { Protein concentration } \\
(\boldsymbol{\mu g} / \mathbf{m L})\end{array}$ & $\begin{array}{c}\text { Antioxidant activity } \\
(\boldsymbol{\mu g} / \mathbf{m L} \text { AAE } / \boldsymbol{\mu g} \text { peptide })\end{array}$ \\
\hline Esperase hydrolysate & 48 & 34 \\
Trypsin hydrolysate & 57 & 38 \\
& Ascorbic acid $_{\text {Control }} \rightarrow(25 \mu \mathrm{g} / \mathrm{mL}$ AAE $/ \mu \mathrm{g}$ ascorbic acid $)$ & \\
\hline
\end{tabular}

\section{Metal chelating activity of peptide hydrolysates}

Metal chelating experiments with different concentrations of peptide hydrolysates were measured. Figure 3 shows the copper chelating activity of trypsin and esperase hydrolyzed $D$. pastinaca muscle. When Figure 4 is evaluated, it is observed that protein hydrolysates prepared with two different enzymes have metal 
chelating activities and as the concentration increases, the activity of the trypsin hydrolysate continues to increase linearly. Even smaller concentrations of trypsin hydrolysate show higher activity compared to esperase.

a

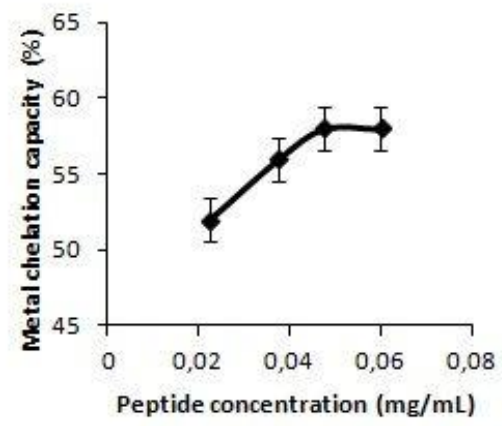

b

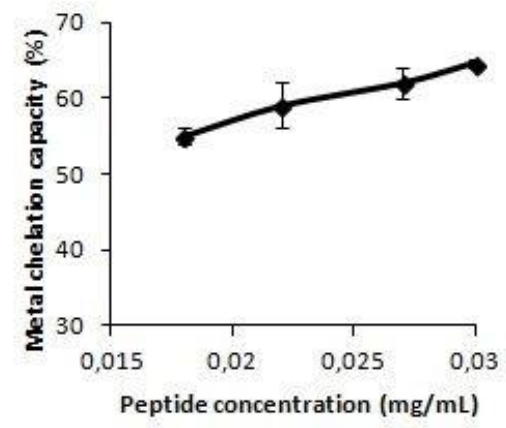

Figure 4. Metal chelating activities of stingray fish muscle hydrolysates: a) Esperase hydrolysate b) Trypsin hydrolysate

\section{DISCUSSION}

D. pastinaca of the Dasyatidae family, commonly called name stingray, is a marine elasmobranch fish and lives in Mediterranean coastal areas [17]. Commercial use of stingrays is limited so they are used merely for local dishes and making exotic leather. In this paper, we investigated antioxidant/metal chelating activities of protein hydrolysates obtained through enzymatic hydrolysis of muscle tissue of $D$. pastinaca.

Esperase is a member of the serine protease class, such as trypsin. However, esperases display very broad substrate specificity, unlike trypsin which cleaves peptides on the C-terminal side of lysine and arginine. Therefore, hydrolysis of the protein required esperase activity twice as much as trypsin activity according to results.

Amino acid composition, structure, and hydrophobicity affect the antioxidative properties of the peptides. For example, amino acids with aromatic residues contribute to the radical-scavenging properties of the peptides [18].In this case, peptides produced by both trypsin and esperase have similar antioxidative properties according to our results. Chai et al. [7] reported that alcalase is the best protease for producing hydrolysates with antioxidant activities (ABTS radical scavenging) comparing to papain and trypsin from blue-spotted stingray (Dasyatis kuhlii). Another study with blue-spotted stingray hydrolyzed with alcalase resulted in two antioxidant peptides with ABTS radical scavenging activity [19]. Peptides from trypsin hydrolyzed red stingray (Dasyatis akajei) cartilage have shown a potential for inhibition of lipid peroxidation activity [8]. Stingrays can be considered as a good source for antioxidant additives when all these findings are taken into account.

We demonstrated that trypsin was more effective than esperase to produce copper chelating peptides. It is possible that trypsin produced peptides with high-affinity metal-binding groups, such as the imidazole and carboxylic groups, electrostatic and ionic interactions with copper may be enforced [20]. As in the antioxidant activity, according to Chai et al. [7], alcalase is more efficient for generating copper chelating peptides from blue-spotted stingray compared to trypsin.

\section{CONCLUSION}

Bioactive peptides have been studied extensively in recent years. As a result of many studies, bioactive peptides have important effects on body functions and contribute to the protection of human health in the treatment of chronic diseases or immune system protection. In this study, we aimed to investigate the antioxidant/metal chelating activities of protein hydrolysates obtained through enzymatic hydrolysis from a natural source. For this purpose, muscle tissue extracts of stingray (D. pastinaca), which had not been studied 
previously, were used as the protein source. E/S ratio and hydrolysis time optimizations were performed for the two different enzymes. When the peptide hydrolysates were evaluated for metal chelation and antioxidant activity, the biological activity of trypsin hydrolysate was found to be better than that of esperase hydrolysate. Further experiments are required for purification/identification and investigating the peptide sequences responsible for antioxidant/metal chelating activities.

\section{REFERENCES}

[1] Sánchez, A., \& Vázquez, A. (2017). Bioactive peptides: A review. Food Quality and Safety, Volume 1, Issue 1, 1 March 2017, 1(1):29-46

[2] Bhat, Z.F., Kumar, S., \& Bhat, H.F. (2015). Bioactive peptides of animal origin: a review. J Food Sci Technol, 52(9):5377-5392

[3] Aneiros, A., \& Garateix, A. (2004). Bioactive peptides from marine sources: pharmacological properties and isolation procedures. Journal of Chromatography B, 803 41-53

[4] Anjum, K., Abbas, S.Q., Akhter, N., Shagufta, B.I., Shah, S.A.A., \& Hassan, S.S.U. (2017).Emerging biopharmaceuticals from bioactive peptides derived from marine organisms. Chem Biol Drug Des. 90(1):12-30

[5] Chalamaiah, M., Dinesh Kumar, B., Hemalatha, R., \& Jyothirmayi, T. (2012). Fish protein hydrolysates: Proximate composition, amino acid composition, antioxidant activities and applications: A review. Food Chemistry, 135:3020-3038

[6] Yeldan, H., Avsar, D., \& Manaşırl, M. (2009). Age, growth and feeding of the common stingray (Dasyatis pastinaca, L., 1758) in the Cilician coastal basin, northeastern Mediterranean Sea. J. Appl. Ichthyol., 25:98-102

[7] Chai, T.T., Tong, S.R., Law, Y.C., Ismail, N.I.M., Manan, F.A., \& Wong, F.C. (2015). Anti-oxidative, metal chelating and radical scavenging effects of protein hydrolysates from blue-spotted stingray. Trop $J$ Pharm Res, 14(8):1349-1355

[8] Pan, X. Y., Wang, Y. M., Li, L., Chi, C. F., \& Wang, B. (2019). Four Antioxidant Peptides from Protein Hydrolysate of Red Stingray (Dasyatis akajei) Cartilages: Isolation, Identification, and In Vitro Activity Evaluation. Marine drugs, 17(5):263

[9] Conceição, K., Konno, K., Melo, R.L., Marques, E.E., Hiruma-Lima, C.A., Lima, C., Richardson, M., Pimenta, D.C., \& Lopes-Ferreira, M. (2006).Orpotrin: A novel vasoconstrictor peptide from the venom of the Brazilian Stingray Potamotrygon gr. orbignyi. Peptides, 27(12):3039-3046

[10] Wong, F.C., Xiao, J., Ong, M.G., Pang, M.J., Wong, S.J., Teh, L.K., \& Chai, T.T. (2019). Identification and characterization of antioxidant peptides from hydrolysate of blue-spotted stingray and their stability against thermal, $\mathrm{pH}$ and simulated gastrointestinal digestion treatments. Food Chemistry, 271: 614-622

[11] Bradford, M. (1976). A rapid and sensitive method for the quantitation of microgram quantities of protein utilizing the principle of protein dye binding. Anal Biochem, 72:248-254

[12] Cupp-Enyard, C. (2008). Sigma's non-specific protease activity assay:casein as a substrate. J. Vis. Exp, 19e899

[13] Erlanger, B.F., Kokowsky, N., \& Cohen, W. (1961). The preparation and properties of two new chromogenic substrates of trypsin. Arch Biochem Biophys, 95(2):271-278 
[14] Zambrowicz, A., Eckert, E., Pokora, M., Dąbrowska, A., Szołtysik, M., Bobak, Ł., Trziszka, T., \& Chrzanowska, J. (2015). Biological activity of egg-yolk protein by-product hydrolysates obtained with the use of non-commercial plant protease. Italian Journal of Food Science, 27.4:450-458

[15] Apak, R., Güçlü, K., Özyürek, M., \& Karademir, S.E. (2004). Novel Total Antioxidant Capacity Index for Dietary Polyphenols and Vitamins C and E, Using Their Cupric Ion Reducing Capability in the Presence of Neocuproine: CUPRAC Method. J. Agric. Food Chem., 52:7970-7981

[16] Nakamura-Takada, Y., Shata, H., Minao, M., Ogawa, H., Sekiguchi, N., Murata, M., \& Homma, S. (1994). Isolation of a zinc-chelating compound from instant coffee by the tetramethyl murexide method. Lebensm Wiss Technol, 27:115-118

[17] Yeldan, H., Avsar, D. \& Manaşırlı, M. (2009). Age, growth and feeding of the common stingray (Dasyatis pastinaca, L., 1758) in the Cilician coastal basin, northeastern Mediterranean Sea. Journal of Applied Ichthyology, 25: 98-102

[18] Sarmadi, B.H.\& Ismail, A. (2010). Antioxidative peptides from food proteins: A review. Peptides, 31(10):1949-1956

[19] Wong, F., Xiao, J., G-Ling Ong, M, Pang, M., Wong, S., Teh, L., \& Chai, T. (2019) Identification and characterization of antioxidant peptides from hydrolysate of blue-spotted stingray and their stability against thermal, pH and simulated gastrointestinal digestion treatments. Food Chemistry, 271:614-622

[20] Zhu, L., Chen, J., Tang, X., \& Xiong, Y.L. (2008). Reducing, Radical Scavenging, and Chelation Properties of in Vitro Digests of Alcalase-Treated Zein Hydrolysate. Journal of Agricultural and Food Chemistry 200856 (8), 2714-2721 